\title{
Pengaruh Budaya Organisasi Dan Karakteristik Individu Terhadap Motivasi dan Kinerja Karyawan Pada PT Perkebunan Nusantara XII Kantor Wilayah I Jember
}

\author{
The Effect of Organizational Culture and Individual Characteristics of \\ Motivation and Performance Employees PT. Perkebunan Nusantara XII \\ Regional Offices I Jember
}

\author{
Iqbal Hadi Nurisman, Diana Sulianti $\mathbf{T}^{\mathbf{1}}$, M.Syaharudin \\ Jurusan Manajemen, Fakultas Ekonomi, Universitas Jember \\ Jln. Kalimantan 37, Jember 68121 \\ E-mail: learn_to@yahoo.com
}

\begin{abstract}
Abstrak
Penelitian ini adalah bertujuan untuk menguji Pengaruh Budaya Organisasi terhadap motivasi, Karakteristik individu terhadap motivasi, budaya organisasi terhadap kinerja karyawan, karakteristik individu terhadap kinerja karyawan dan motivasi terhadap kinerja karyawan PT.Perkebunan Nusantara XII (Persero) Kantor Wilayah I Jember. Populasi dalam penelitian ini adalah karyawan PT.Perkebunan Nusantara XII (Persero) Kantor Wilayah I Jember yang berjumlah 37 karyawan. Metode sampling yang digunakan adalah metode sensus dengan jumlah responden sebanyak 37 orang. Variabel digunakan yaitu sebanyak 4 variabel. Alat analisis yang digunakan adalah Analisis Jalur (Path Analyse). Hasil penelitian menunjukkan bahwa : 1) Ada pengaruh budaya organisasi terhadap motivasi karyawan pada PT Perkebunan Nusantara XII(Persero) kantor wilayah I Jember ; 2) Ada pengaruh karakteristik individu terhadap motivasi karyawan pada PT.Perkebunan Nusantara XII(Persero) kantor wilayah I Jember, 3) Ada pengaruh budaya organisasi terhadap kinerja karyawan pada PT.Perkebunan Nusantara XII(Persero) kantor wilayah I Jember, 4) Ada pengaruh karakteristik individu terhadap kinerja karyawan pada PT.Perkebunan Nusantara XII(Persero) kantor wilayah I Jember, dan 5) Ada pengaruh motivasi terhadap kinerja karyawan pada PT.Perkebunan Nusantara XII(Persero) kantor wilayah I Jember.
\end{abstract}

Kata kunci : Budaya Organisasi, Karakteristik Individu, Motivasi, Kinerja Karyawan

\begin{abstract}
This research aims to examine the effect of organitation culture on motivation, individual characteristics on motivation, organitation culture on performance of employees, individual characteristics on performance of employees, and motivation on performance of employees in PT. Perkebunan Nusantara XII Regional Office I Jember. The population in this research is all employees of PT. Perkebunan Nusantara XII Regional Office I Jember. The sampling method used was sensus method.with respondent total as many as 37 people. Variables used as many as four variables; organizational culture, individual characteristics, motivation, and performance of employees. The analysis tool used is the path analysis (path analysis). The results showed that: 1) There is influence of organizational culture on motivation in PT. Perkebunan Nusantara XII Regional Office I Jember; 2) There is influence of individual characteristic on employees motivation in PT. Perkebunan Nusantara XII Regional Office I Jember; 3) There is influence of organizational culture on performance of employees in PT. Perkebunan Nusantara XII Regional Office I Jember; 4) There is effect of individual characteristics on employees performance PT. Perkebunan Nusantara XII Regional Office I Jember; and 5) There is effect of motivation on performance of employees PT. Perkebunan Nusantara XII Regional Office I Jember.
\end{abstract}

Keywords : Organizational Culture, Individual Characteristics, Motivation, Performance of Imployees

\section{Pendahuluan}

Seiring dengan berkembangnya zaman menuju arah yang lebih modern, perlu disadari pola fikir masyarakat juga semakin berkembang, salah satunya di bidang ekonomi. Perkembangan di bidang ekonomi semakin hari semakin ketat dalam persaingan dan mengharuskan perusahaan untuk mengembangkan segala potensi yang ada di dalam perusahaannya untuk terus berinovasi, terutama di bidang sumber daya manusia. Potensi setiap sumber daya manusia yang ada dalam perusahaan harus dapat dimanfaatkan dengan sebaik-baiknya sehingga mampu memberikan output optimal. Oleh karena itu, perusahaan juga dituntut untuk mampu mengidentifikasi hal-hal apa saja yang menjadi kendala atau permasalahan di dalam menjalankan kegiatan

1 Corresponding author

e-Journal Ekonomi Bisnis dan Akutansi, 2017, Volume IV (1) : 92-96 
dan aktivitas ekonomi, termasuk masalah Kinerja karyawannya dimana setiap perusahaan memiliki budaya organisasi yang berbeda dan karakteristik karyawan yang berbeda pula.

Banyak faktor yang mendorong dan mempengaruhi sumber daya manusia yang dimiliki perusahaan agar bergerak kearah positif. Perlakuan terhadap tenaga manusia tentunya berbeda dengan perlakuan terhadap faktor produksi yang lainnya, karena tenaga manusia memiliki karakteristik yang berbedabeda. Disinilah tantangan bagi perusahaan untuk mengatur berbagai macam kekhususan yang dimiliki tenaga kerja yaitu karyawan guna mencapai tujuan perusahaan. Budaya organisasi adalah salah satu faktor yang mempengaruhi tendensi anggota untuk tetap bersama organisasi dan menjaga loyalitasnya. Menurut Tika (2008:65) budaya organisasi adalah nilai dan praktik yang memiliki bersama diseluruh kelompok dalam satu perusahaan, sekurang-kurangnya dalam manajemen senior dan definisi antara budaya organisasi dan budaya perusahaan saling terkait karena kedua-duanya memiliki kesamaan, meskipun dalam budaya organisasi terdapat hal-hal khusus sebagai gaya manajemen, sistem manajemen, dan sebagainya, namun semuanya tetap dalam rangkaian budaya organisasi. Budaya organisasi membentuk nilai dan standar yang menuntun perilaku organisasi, kondisi tersebut dapat menentukan arah dari seluruh tujuan perusahaan. Budaya organisasi merupakan nilai-nilai bersama dan kepercayaan yang diberikan oleh anggota pada organisasi yang kemudian menghasilkan aturan-aturan berperilaku dalam keseharian berorganisasi. Suatu budaya organisasi yang kuat memperlihatkan kesepakatan yang tinggi di kalangan anggota yang dipegang teguh dan disepakati bersama. Kuat lemahnya budaya suatu organisasi sangat bergantung pada bagaimana anggota mengaplikasikannya pada kehidupan berorganisasi dalam perusahaan. Budaya organisasi yang baik diharapkan mampu memberikan kenyamanan anggota atau karyawan dalam bekerja dan mampu memberikan peningkatan kinerja yang optimal, sehingga karyawan mampu memenuhi ekspetasi yang diharapkan oleh perusahaan.

Selain budaya organisasi perusahaan juga harus mampu menganalisis dan menyelesaikan permasalahan yang kecil namun menentukan tujuan perusahaan akan berjalan dengan baik atau tidak, hal kecil itu yaitu karakteristik individu dari karyawan-karyawan sendiri. karakteristik karyawan yang berbeda-beda akan menjadi suatu permasalahan yang fatal apabila perusahaan, khususnya manajer tidak mampu membawa perbedaan tersebut menjadi satu visi dan misi demi tujuan perusahaan itu sendiri. Perbedaan yang tercermin itu diharapkan memberikan keunikan dan keragaman dalam suatu perusahaan dalam meningkatkan kinerja karyawan maupun memberikan inovasi-inovasi, ataupun ide-ide gagasan yang mampu memberikan keuntungan dan kemajuan perusahaan. Namun, karena perbedaan karakteristik itu permasalahan antar karyawan tidak dapat dipungkiri akan terjadi, seperti hal persaingan dalam bekerja ataupun hal-hal lain yang mampu membuat penurunan kinerja karyawan dan menjadikan suasana dalam perusahaan menjadi tidak kondusif, disini perusahaan diharuskan mampu menengahi dan meminimalisir hal-hal tersebut. Perusahaan diharapkan peka dan mampu memberikan motivasi-motivasi yang mampu mengkondusifkan suasana dalam perusahaan itu sendiri.

Sama halnya dengan budaya organisasi dan karakteristik individu yang berbeda-beda, motivasi dari perusahaan juga merupakan suatu hal yang sangat perlu diperhatikan dalam meningkatkan kinerja karyawan sesuai tujuan perusahaan. Motivasi menurut Robbin (2002:23) adalah kesediaan untuk mengeluarkan tingkat upaya yang tinggi kearah tujuan organisasi, yang dikondisikan oleh kemampuan itu untuk memenuhi sesuatu kebutuhan individu. Motivasi merupakan faktor yang mampu memberikan pengaruh yang besar bagi pegawai, baik motivasi dari perusahaan ataupun motivasi yang datang dari diri sendiri. Motivasi yang tepat akan menentukan tingkatan prestasi pegawai, yang pada akhirnya akan mempengaruhi efektifitas pencapaian tujuan organisasi. Motivasi merupakan hal yang mampu membuat seseorang melakukan sesuatu hal dengan baik dari sebelumnya, disini perusahaan, khususnya manajer diharapkan mampu menggunakan faktor-faktor motivasi secara tepat dalam rangka mengarahkan karyawan agar bisa bekerja dengan lebih efektif dan produktif bagi organisasi kerjanya.

Dari semua faktor-faktor diatas, perusahaan meengharapkan karyawan mampu meningkatkan kinerjanya sesuai dengan ekspetasi perusahaan, atau bahkan mampu melebihi apa yang diharapakan. Kinerja menurut wibowo (2010:22) adalah hasil kerja karyawan dilihat dari aspek kualitas, kuantitas, waktu kerja sama untuk mencapai tujuan yang sudah ditetapkan oleh perusahaan. Sehingga dalam aplikasinya peningkatan kinerja karyawan merupakan hal yang sangat penting dalam kemajuan karyawan itu sendiri dan perusahaan. Yang pada akhirnya perusahaan menginginkan mampu bersaing dan mampu mengembangkan usaha dan mendapatkan profitabilitas melalui segala kebijakan dan ketentuan yang diberikan kepada karyawannya. Hal ini juga tidak lepas apa yang dilakukan dan diberikan PT.Perkebunan Nusantara XII Jember kepada karyawan-karyawannya.

PT Perkebunan Nusantara XII (Persero) disingkat dengan PTPN XII merupakan Badan Usaha Milik Negara, dengan kata lain karyawan yang dipekerjakan juga mencakup seluruh Indonesia. Perbedaan kebudayaan atau kebiasaan karyawan dari tempat asal masing-masing pasti menjadi masalah yang tidak dapat dihindari, belum lagi karakteristik individu tiap karyawan yang beragam. Oleh karena itu, PT Perkebunan Nusantara XII(Persero) dituntut untuk mampu menciptakan suatu budaya organisasi yang mampu menyatukan dan memberikan kenyamanan karyawan dalam bekerja, serta tanggap dalam menangani perbedaan karakteristik karyawannya. Kebijakan-kebijakan yang tepat sangat diperlukan PT Perkebunan Nusantara XII untuk memotivasi dan meningkatkan kinerja karyawan. Budaya organisasi seperti apakah yang harus digunakan dalam menyikapi perbedaan karakteristik individu, sekaligus mampu memotivasi dan meningkatkan kinerja karyawan menjadi masalah paling utama, oleh karena ittu Dari latar belakang inilah penulis ingin mengetahui apakah budaya organisasi dan karakteristik individu tiap karyawan mampu mempengaruhi motivasi serta kinerja dari karyawan itu sendiri. 


\section{Metode}

\section{Populasi dan Sampel}

Dalam penelitian ini, populasinya adalah karyawan PT. Perkebunan Nusantara XII (Persero) Jember yang berjumlah 37 orang, Dari populasi tersebut diambil semua sebagai sampel dengan cara metode sensus.

\section{Metode Analisis}

Analisis jalur merupakan bagian dari analisis regresi linier yang digunakan untuk menganalisis hubungan kausal antar variabel dimana variabel-variabel bebas mempengaruhi variabel terikat, baik secara langsung maupun tidak langsung melalui satu atau lebih perantara.

Mekanisme analisa jalur adalah :

Konsep uji yang digunakan didalam penelitian ini adalah a) Konsep uji digunakan untuk mengetahui variabel independen, yaitu budaya organisasi $\left(\mathrm{X}_{1}\right)$, dan Karakteristik Individu $\left(\mathrm{X}_{2}\right)$ berpengaruh terhadap variabel intervening, yaitu motivasi (Z); b) Konsep uji digunakan untuk mengetahui variabel independen, yaitu budaya organisasi $\left(\mathrm{X}_{1}\right)$, dan karakteristik individu $\left(\mathrm{X}_{2}\right)$, berpengaruh terhadap variabel dependent, yaitu Kinerja karyawan (Y), dan; c) Konsep uji digunakan untuk mengetahui variabel motivasi(Z) berpengaruh terhadap variabel dependent, yaitu kinerja karyawan $(\mathrm{Y})$;

Data yang diolah akan dilakukan trimming theory jika terjadi pengaruh yang tidak signifikan pada masing-masing variabel, apabila budaya organisasi $\left(\mathrm{X}_{1}\right)$, atau karakteristik individu $\left(\mathrm{X}_{2}\right)$ tidak berpengaruh terhadap variabel intervening, yaitu motivasi (Z).

Model analisis jalur yang digunakan dalam penelitian ini dapat diuraikan dalam persamaan struktural berikut :

$$
\begin{aligned}
& Z=\beta 0+\beta X_{1} Z+\beta X_{2} Z \ldots \ldots \ldots \ldots \ldots . .(\text { persamaan } 1) \\
& Y=\beta 0+\beta X_{1} Y+\beta X_{2} Y+\beta Z Y \ldots \ldots \ldots .(\text { persamaan } 2)
\end{aligned}
$$

\section{Hasil Dan Pembahasan}

\section{Pengujian Instrumen}

Uji validitas sebagai alat ukur dalam penelitian ini, yaitu menggunakan korelasi product moment pearson's, yaitu dengan cara mengkorelasikan tiap pernyataan dengan skor total, kemudian hasil korelasi tersebut dibandingkan dengan angka kritis taraf signifikan 5\%.

Berdasarkan tabel 5, diketahui bahwa masing-masing indikator (item) dalam variabel yang digunakan mempunyai hasil nilai product moment pearson's dengan signifikasi 0,000 $<0,05$, sehingga indikator (item) yang digunakan dalam variabel penelitian ini dapat dinyatakan relevan dan dapat digunakan sebagai alat dalam pengumpulan data

\begin{tabular}{|c|c|c|c|c|}
\hline Variabel & $\begin{array}{c}\text { Product } \\
\text { Moment } \\
\text { Pearson's }\end{array}$ & Sig. & $a$ & Keterangan \\
\hline $\mathrm{X}_{1.1}$ & 0,467 & 0,004 & 0,05 & Valid \\
\hline $\mathrm{X}_{1.2}$ & 0,414 & 0,011 & 0,05 & Valid \\
\hline $\mathrm{X}_{1.3}$ & 0,376 & 0,022 & 0,05 & Valid \\
\hline $\mathrm{X}_{1.4}$ & 0,371 & 0,024 & 0,05 & Valid \\
\hline $\mathrm{X}_{1.5}$ & 0,624 & 0,000 & 0,05 & Valid \\
\hline $\mathrm{X}_{1.6}$ & 0,545 & 0,000 & 0,05 & Valid \\
\hline $\mathrm{X}_{2.1}$ & 0,663 & 0,000 & 0,05 & Valid \\
\hline $\mathrm{X}_{2.2}$ & 0,522 & 0,001 & 0,05 & Valid \\
\hline $\mathrm{X}_{2.3}$ & 0,700 & 0,000 & 0,05 & Valid \\
\hline $\mathrm{X}_{2.4}$ & 0,578 & 0,000 & 0,05 & Valid \\
\hline$Z_{1}$ & 0,703 & 0,000 & 0,05 & Valid \\
\hline$Z_{2}$ & 0,792 & 0,000 & 0,05 & Valid \\
\hline $\mathrm{Z}_{3}$ & 0,710 & 0,000 & 0,05 & Valid \\
\hline $\mathrm{Z}_{4}$ & 0,630 & 0,000 & 0,05 & Valid \\
\hline $\mathrm{Z}_{5}$ & 0,666 & 0,000 & 0,05 & Valid \\
\hline $\mathrm{Y}_{1}$ & 0,588 & 0,000 & 0,05 & Valid \\
\hline $\mathrm{Y}_{2}$ & 0,675 & 0,000 & 0,05 & Valid \\
\hline $\mathrm{Y}_{3}$ & 0,669 & 0,000 & 0,05 & Valid \\
\hline $\mathrm{Y}_{4}$ & 0,528 & 0,001 & 0,05 & Valid \\
\hline $\mathrm{Y}_{5}$ & 0,578 & 0,000 & 0,05 & Valid \\
\hline $\mathrm{Y}_{6}$ & 0,690 & 0,000 & 0,05 & Valid \\
\hline
\end{tabular}

Tabel 5 Hasil Uji Validitas

Sumber : data diolah, 2014

Uji reliabilitas menggunakan crobach's alpha. Suatu instrument dikatakan reliabel apabila crobach's alpha lebih besar dari 0,60 .

Tabel 6 Hasil Uji Reliabilitas

\begin{tabular}{ccccc}
\hline $\begin{array}{c}\text { Variabe } \\
\mathrm{l}\end{array}$ & $\begin{array}{c}\text { Cronbach's } \\
\text { Alpha }\end{array}$ & $\begin{array}{c}\text { Cut } \\
\text { off }\end{array}$ & N of Item & Keterangan \\
\hline $\mathrm{X}_{1}$ & 0,674 & 0,6 & 6 & Reliabel \\
$\mathrm{X}_{2}$ & 0,644 & 0,6 & 4 & Reliabel \\
$\mathrm{Z}$ & 0,733 & 0,6 & 5 & Reliabel \\
$\mathrm{Y}$ & 0,675 & 0,6 & 6 & Reliabel \\
\hline
\end{tabular}

Sumber : data diolah, 2014

Berdasarkan Tabel 6, hasil uji reliabilitas diatas menunjukkan bahwa data yang diperoleh bersifat reliabel karena nilai Cronbach's Alpha yakni 0,674, 0,644, 0,733, dan 0,675 > 0,60 , sehingga data yang diperoleh dapat dinyatakan reliabel atau layak sebagai alat dalam pengumpulan data. 
Uji normalitas yang dilakukan terhadap sampel dilakukan dengan mengunakan kolmogorov-smirnov test dengan menetapkan derajat keyakinan $(\alpha)$ sebesar 5\%

Tabel 7 Hasil Uji Normalitas

\begin{tabular}{cccc}
\hline \multirow{2}{*}{$\begin{array}{r}\text { Test of } \\
\text { Normality }\end{array}$} & \multicolumn{3}{c}{ Kolmogorov-Smirnov } \\
\cline { 2 - 4 } & Sig. & Cutt & Keterangan \\
\hline $\mathrm{X}_{1}$ & 0,103 & 0,05 & Normal \\
$\mathrm{X}_{2}$ & 0,068 & 0,05 & Normal \\
$\mathrm{Z}$ & 0,115 & 0,05 & Normal \\
$\mathrm{Y}$ & 0,083 & 0,05 & Normal \\
\hline
\end{tabular}

Sumber : data diolah, 2014

Berdasarkan tabel 7, dapat diketahui bahwa nilai probabilitas atau signifikansi untuk masing-masing variabel lebih besar dari 0,05 , sehingga dapat dinyatakan bahwa data dalam penelitian ini berdistribusi normal.

\section{Analisis Jalur}

Analisis jalur berkaitan dengan studi ketergantungan suatu variabel dependen pada satu atau lebih variabel independen atau intervening dengan tujuan untuk mengetahui seberapa besar pengaruh variabel independen atau intervening terhadap variabel dependen. Hasil analisis jalur, yaitu : 1) Pengaruh variabel budaya organisasi terhadap motivasi kerja adalah sebesar $37,1 \%$; 2) Pengaruh variabel karakteristik individu terhadap motivasi adalah sebesar 31,2\%; 3) Pengaruh variabel budaya organisasi terhadap kinerja karyawan adalah sebesar 46,2\%; 4) Pengaruh variabel karakteristik individu terhadap kinerja karyawan adalah sebesar 38,3\%; 5) Pengaruh variabel motivasi terhadap kinerja karyawan adalah sebesar 76,6\%

\section{Tabel 8. Hasil Analisis Jalur}

\begin{tabular}{|c|c|c|c|c|c|c|}
\hline \multicolumn{2}{|c|}{$\begin{array}{c}\text { Unstanderdize } \\
d\end{array}$} & \multirow{2}{*}{$\mathrm{t}_{\text {hitung }}$} & \multirow{2}{*}{$t_{\text {tabel }}$} & \multirow{2}{*}{ Sig. } & \multirow{2}{*}{$a$} & \multirow{2}{*}{ Ket } \\
\hline Jalur & $\begin{array}{l}\text { Beta } \\
(\beta)\end{array}$ & & & & & \\
\hline$X_{1} \rightarrow Z$ & 0,371 & 2,446 & 1,691 & 0,020 & 0,05 & Sig \\
\hline $\mathrm{X}_{2} \rightarrow \mathrm{Z}$ & 0,312 & 2,056 & 1,691 & 0,048 & 0,05 & Sig \\
\hline $\mathrm{X}_{1} \rightarrow \mathrm{Y}$ & 0,462 & 3,514 & 1,691 & 0,001 & 0,05 & Sig \\
\hline $\mathrm{X}_{2} \rightarrow \mathrm{Y}$ & 0,383 & 2,914 & 1,691 & 0,006 & 0,05 & Sig \\
\hline $\mathrm{Z} \rightarrow \mathrm{Y}$ & 0,766 & 7,044 & 1,691 & 0,000 & 0,05 & Sig \\
\hline$\varepsilon 1$ & 0,66 & - & - & - & - & - \\
\hline$\varepsilon 2$ & 0,549 & - & - & - & - & - \\
\hline
\end{tabular}

Sumber : Data diolah, 2014

Berdasarkan koefisien jalur pada Tabel 8, maka persamaan yang dapat dibentuk adalah :

$Z=0,371 X_{1}+0,312 X_{2}+0,66 \varepsilon 1$

$\mathrm{Y}=0,462 \mathrm{X}_{1}+0,383 \mathrm{X}_{2}+0,766 \mathrm{Z}+0,549 \varepsilon 2$

\section{Pembahasan}

\section{Pengaruh Budaya Organisasi Terhadap Motivasi}

Penelitian yang dilakukan, menunjukkan bahwa nilai koefisien variabel budaya organisasi sebesar 0,371 atau $37,1 \%$. Budaya organisasi sebagai suatu kerangka kerja kognitif yang memuat sikap-sikap, nilai-nilai, norma-norma, dan pengharapan-pengharapan bersama yang dimiliki oleh anggota-anggota organisasi atau sebuah persepsi umum yang dipegang teguh oleh para anggota organisasi, dengan artian bahwa adanya instansi yang mendorong dan menghargai prestasi dari karyawannya untuk terus menerus meningkatkan inovasi dan kreativitas yang tinggi. Budaya organisasi membentuk latar belakang yang berkaitan dengan lingkungan, kondisi kerja, sikap, perilaku serta persepsi karyawan pada organisasi tempat mereka bekerja mempengaruhi motivasi karyawan dalam melakukan pekerjaan dengan baik dan sesuai yang diinginkan perusahaan. Budaya organisasi yang baik akan membentuk suatu pengaruh positif terhadap motivasi karyawan dalam meningkatkan kinerja (Robbins, 2006:38).

\section{Pengaruh Karakteristitk Individu Terhadap Motivasi}

Penelitian yang dilakukan, menunjukkan bahwa nilai koefisien variabel karakteristik individu sebesar 0,312 atau $31,2 \%$. Dengan artian bahwa adanya karyawan yang memiliki kemampuan kerja yang baik, adanya rasa nyaman didalam kerjasama tim kerja yang dibentuk, adanya ketanggapan karyawan dan adanya rasa dan minat didalam berkerja, telah menjadikan karyawan lebih bergairah dan sesuai didalam berkerja sehingga karyawan yang berkerja akan senantiasa berkerja cepat dan tepat sesuai dengan instruksi yang telah diberikan oleh instansi. Motivasi terbentuk dari sikap karyawan dalam menghadapi situasi kerja di perusahaan. Motivasi merupakan kondisi yang menggerakkan diri karyawan yang terarah untuk mencapai tujuan organisasi. Mangkunegara (2005:61), mengemukakan bahwa sikap mental karyawan yang pro dan aktif terhadap situasi kerja itulah yang memperkuat motivasi kerjanya untuk mencapai kerja yang maksimal. Karyawan yang termotivasi dari kebijakan-kebijakan dari perusahaan akan secara sukarela meningkatkan kinerjanya untuk mencapai sesuatu yang diinginkan, baik apa yang diinginkan diri sendiri ataupun yang diinginkan perusahaan.

\section{Pengaruh Budaya Organisasi Terhadap Kinerja Karyawan}

Penelitian yang dilakukan, menunjukkan bahwa nilai koefisien variabel budaya organisasi sebesar 0,462 atau $46,2 \%$. Dengan artian bahwa adanya inovasi terhadap pengambilan resiko kerja, perhatian terhadap tugas, adanya sistem kerja yang berorientasi hasil dan berorientasi atas kerjasama tim kerja, dan adanya kemantapan didalam menjaga nilai-nilai didalam organisasi, telah menjadikan karyawan lebih bijaksana didalam mengambil keputusan didalam berkerja sehingga hasil dan kualitas kerja yang diharapkan oleh perusahaan dapat tercapai. Berbagai tindakan yang dilakukan oleh seseorang tentunya berbeda-beda. Dalam organisasi, implementasi budaya disajikan dalam bentuk perilaku, yang artinya perilaku individu dalam organisasi akan diwarnai oleh budaya organisasi yang bersangkutan. Dalam sebuah perusahaan atau organisasi tentunya perilaku individu diarahkan dengan tujuan untuk mencapai tujuan 
utama perusahaan, seperti yang diungkapkan oleh Moleenar (2002:23), bahwa budaya organisasi yang disosialkan dengan komunikasi yang baik dapat menentukan kekuatan perusahaan, kinerja dan daya saing dalam jangka panjang. Budaya organisasi yang baik akan menghasilkan kinerja yang baik pula bagi karyawan-karyawannya.

\section{Pengaruh Karakteristik Individu terhadap Kinerja} Karyawan

Penelitian yang dilakukan, menunjukkan bahwa nilai koefisien variabel karakteristik individu sebesar 0,383 atau $38,3 \%$. dengan artian bahwa adanya karyawan yang mampu menyelesaikan pekerjaannya dengan tepat waktu, adanya sikap yang harmonis yang disukai karyawan didalam berinteraksi dengan rekan kerjanya, adanya ketanggapan antar karyawan didalam instasi, dan adanya pekerjaan yang sesuai dengan kemampuan dan minat karyawannya, telah menjadikan karyawan dapat lebih berdisiplin didalam berkerja sehingga tanggungjawab kerja yang ada didalam instansi dapat terselesaikan dengan batas waktu yang telah ditentukan oleh instansi. Karakkteristik individu yang berbeda juga dapat memberikan warna yang berbeda pada suatu perusahaan. Perusahaan harus mampu melihat dan membaca apa yang harus dilakukan untuk meningkatkan kinerja karyawan dengan karakteristik yang dimiliki oleh masingmasing karyawan. Masing-masing karyawan memiliki potensi dan kebutuhan yang berbeda, oleh karena itu perusahaan dituntut mampu memahami perilaku-perilaku karyawan yang tejadi dalam perusahaan. Keputusan dan kebijakan perbedaan karakteristik individu yang tepat akan meningkatkan kinerja karyawan, yang berujung pada tercapainya tujuan perusahaan (Robbins, 2001:187).

\section{Pengaruh Motivasi Terhadap Kinerja Karyawan}

Penelitian yang dilakukan, menunjukkan bahwa nilai koefisien variabel motivasi kerja sebesar 0,766 atau 76,6\%. Dengan artian bahwa adanya kebutuhan fisik karyawan yang telah terpenuhi, adanya jaminan kerja yang diberikan oleh karyawannya didalam berkerja, adanya situasi kerja yang nyaman dan adanya kesempatan untuk karyawan didalam mengaktualisasikan kreasi kerjanya, telah menjadikan karyawan lebih bersemangat dan terdorong didalam berkerja sehingga tugas kerja dan kerjasama tim kerja yang dibentuk oleh instansi dapat memberikan hasil yang baik dan sesuai dengan harapan instansi. Motivasi terbentuk dari sikap karyawan dalam menghadapi situasi kerja di dalam perusahaan. Menurut Simamora (2004:456) motivasi adalah dorongan psikologis yang mengarahkan seseorang menuju sebuah tujuan. Motivasi sebagai upaya yang dapat memberikan dorongan kepada seseorang untuk mengambil suatu tindakan yang dikehendaki. Motivasi yang baik akan mendorong karyawan untuk berbuat sebaik mungkin dalam melaksanakan tugas yang diberikan, sehingga kinerja karyawan akan terpelihara dengan baik.

\section{Simpulan}

\section{Kesimpulan}

Berdasarkan hasil penelitian, dapat disimpulkan sebagai berikut ; 1) Budaya organisasi berpengaruh terhadap motivasi kerja karyawan PT. Perkebunan Nusantara XII Kantor Wilayah I Jember dengan arah positif; 2) Karakteristik individu berpengaruh terhadap motivasi kerja karyawan PT. Perkebunan Nusantara XII Kantor Wilayah I Jember dengan arah positif; 3) Budaya organisasi berpengaruh terhadap kinerja karyawan PT. Perkebunan Nusantara XII Kantor Wilayah I Jember dengan arah positif; 4) Karakteristik Individu berpengaruh terhadap kinerja karyawan PT. Perkebunan Nusantara XII Kantor Wilayah I Jember dengan arah positif; 5) Motivasi kerja berpengaruh terhadap kinerja karyawan PT. Perkebunan Nusantara XII Kantor Wilayah I Jember dengan arah positif.

\section{Keterbatasan}

Keterbatasan didalam penelitian ini adalah : Penelitian ini menganalisis variable yang tidak terukur langsung dan juga memiliki sifat hubungan yang structural, oleh karena itu melihat dari karakteristik yang dimiliki tersebut model analisis yang sesuai seharusnya adalah analisis SEM, sedangkan dalam penelitian ini menggunakan analisi Path yang lebih sesuai untuk variable yang terukur langsung.

\section{Referensi}

Mangkunegaran, AA. Anwar Prabu. 2005. Manajemen Sumber Daya Manusia Perusahaan. Remaja Rosdakarya. Bandung

Robbins, Stephen P. 2001. Perilaku Organisasi Jilid 1 Dan 2 PT.Prenhallindo. Jakarta

Robbins, Stephen P. 2002. Prinsip-Prinsip Perilaku Organisasi. Erlangga. Jakarta

Robbins, Stephen P. 2006. Perilaku Organisasi : Konsep, Kontorversi, Aplikasi. Edisi Kesepuluh, Prenhallindo. Kelompok Gramedia. Jakarta

Simamora, Henry. 2004. Manajemen Sumber Daya Manusia. STIE YKPN. Yogyakarta

Tika, Moh. Pabundu. 2008. Metodologi Riset Bisnis. PT Bumi Aksara. Jakarta 